\title{
Ammonium Niobium Oxalate (ANO)
}

\author{
Lorena Fortes ${ }^{\mathrm{a}}$ \\ Pamella M. Monte ${ }^{\mathrm{a}}$ \\ Anna Paula P. M. da Silva \\ José C. Barros*a ${ }^{*}$ \\ Tiago L. da Silvab
}

a Universidade Federal do Rio de Janeiro, Instituto de Química,

Avenida Athos da Silveira Ramos, $n^{\circ} 149$, Bloco A, $7^{\circ}$ andar, Centro de Tecnologia,

Cidade Universitária, Rio de Janeiro, RJ, CEP: 21941-909, Brasil

jbarros@iq.ufrj.br

' Universidade Federal do Rio de Janeiro, Campus Macaé,

Avenida Aluizio da Silva Gomes, n 50, Granja dos Cavaleiros,

Macaé, RJ, CEP: 27930-560, Brasil

\begin{abstract}
Received: 03.08.2021
Accepted after revision: 18.08.2021

Published online: 19.08 .2021

DOI: 10.1055/a-1592-3655; Art ID: so-2021-d0040-spot

License terms: $c(1) \ominus$

(c) 2021. The Author(s). This is an open access article published by Thieme under the terms of the Creative Commons Attribution-NonDerivative-NonCommercial-License, permitting copying and reproduction so long as the original work is given appropriate credit. Contents may not be used for commercial purposes or adapted, remixed, transformed or built upon. (https://creativecommons.org/licenses/by-nc-nd/4.0/)
\end{abstract}

Key words catalysis, niobium, organic synthesis, green chemistry, ANO

Niobium is a metal, the majority of reserves of which are found in Brazil. ${ }^{1}$ Ammonium niobium oxalate (ANO, Figure 1 ) is a white powder, odorless, stable, nonexplosive, easy to handle, water-soluble, and with low toxicity. ANO has the molecular formula of $\mathrm{NH}_{4}\left[\mathrm{NbO}\left(\mathrm{C}_{2} \mathrm{O}_{4}\right)_{2}\left(\mathrm{H}_{2} \mathrm{O}\right)_{2}\right] \cdot \mathrm{xH}_{2} \mathrm{O}$, where the niobium atom is coordinated by two groups of bidentate oxalates linked to two water molecules and an oxygen atom, forming a pentagonal bipyramid with a double bond, $\mathrm{Nb}=\mathrm{O}$. The ammonium group is surrounded by seven oxygen atoms, belonging to the oxalate group and the niobium group in an irregular arrangement. ANO is widely used as a starting material for the preparation of oxides, mixtures of oxides, or as a support for heterogeneous catalysts in chemical reactions. It is produced by the addition of niobic acid and ammonium oxalate to an aqueous solution of oxalic acid. ${ }^{2}$

In organic synthesis, ANO behaves as a Lewis acid, but its role as a catalyst is still under-represented in the literature, even though it is a readily available and inexpensive compound (ca. USD 750/kg). ${ }^{3}$ These features together with its water-solubility render this compound a promising catalyst in Green Chemistry. ${ }^{4}$

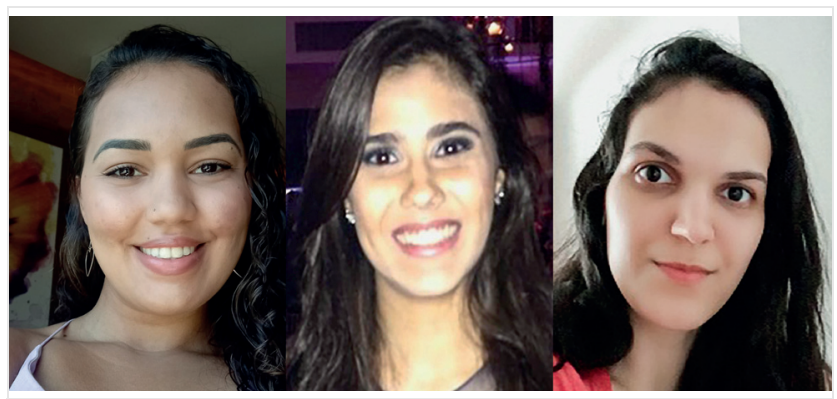

Lorena Fortes and Pamella M. Monte are undergraduate students, and Anna Paula P. M. da Silva is a graduate student at Universidade Federal do Rio de Janeiro - UFRJ/Brazil. Their research interests involve the use of several $\mathrm{Nb}$ compounds as catalysts in the preparation of heterocycles. José C. Barros and Tiago L. da Silva supervised the students in their projects.

Herein, a highlight of several applications developed for ANO over recent years is presented, and where possible, a comparison with traditional catalysts will be shown. As a new niobium catalyst, it is currently being tested by groups within Brazil against established methodologies as a proof of concept of its usefulness. However, the very mild reaction conditions indicate ANO has the potential to enter the chemist's Lewis acid toolbox and reach a global audience.

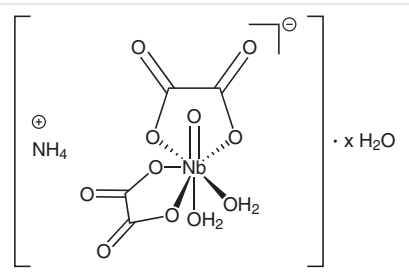

Figure 1 Niobium ammonium oxalate (ANO) structure 
Table 1 Applications of Ammonium Niobium Oxalate (ANO)

(A) Bis(indolyl)methanes (BIMs) are important compounds due to their biological and pharmacological properties, such as antibacterial, anti-inflammatory, and antibiotic activity. ANO was applied as a catalyst to prepare BIMs following Green Chemistry principles. Initially, the reaction conditions were optimized using indole and benzaldehyde in water. The best result was obtained with $5 \mathrm{~mol} \%$ of catalyst at $50{ }^{\circ} \mathrm{C}$ under conventional heating for $2 \mathrm{~h}$ ( $97 \%$ yield). This reaction was also performed under ultrasonic irradiation in glycerol using the same amount of catalyst at a final temperature of $110^{\circ} \mathrm{C}$ for $3 \mathrm{~min}$ ( $99 \%$ conversion of indole). The recycling of the catalyst was studied in both reactions. Using water as the solvent, the catalyst could be reused up to 5 times without loss of activity and the reaction yield remained the same. However, using glycerol as the solvent, the catalyst was inactive after the first use. ${ }^{\text {5a }}$ Starting from unactivated 5 -bromo- $1 \mathrm{H}$-indole and 4-methylbenzaldehyde, the respective BIM was obtained in better yield than when using catalysts such as sulfonic acid functionalized ionic liquid, ${ }^{5 \mathrm{~b}}$ ferrous oxalate, ${ }^{5 \mathrm{c}}$ $\mathrm{PdCl}_{2}(\mathrm{MeCN})_{2}$, ${ }^{5 \mathrm{~d}}$ or tetramethyl guanidinium chlorosulfonate. ${ }^{5 \mathrm{e}}$

(B) 2-Substituted benzothiazoles are present in various bioactive molecules and 1,4-benzoxazine-containing compounds have pharmacological and biological activities. ANO was used as a catalyst to develop a new methodology to obtain 2-substituted benzothiazoles and 3-substituted 1,4-benzoxazin-2ones from $\alpha$-phenylglyoxylic acid (PGA) using PEG-400 as solvent. At first, the study focused on optimizing the reaction conditions in the formation of 2-arylbenzothiazoles under conventional heating. The best result was obtained in the reaction between PGA and 2-aminothiophenol using $10 \mathrm{~mol} \%$ of ANO and PEG-400 as solvent at $100{ }^{\circ} \mathrm{C}$ for $2 \mathrm{~h}$ ( $85 \%$ yield). This methodology has been applied to different $\alpha$-arylglyoxylic acids and 2 -aminophenols to produce 3substituted $2 \mathrm{H}$-benzo[ $b][1,4]$ benzoxazine-2-ones. In general, the yields obtained were good (the majority over $70 \%)$. These reactions were performed under ultrasonic irradiation as well and the yields were satisfactory after a few minutes of reaction (over $85 \%$ yield). ${ }^{6 a}$ For the methyl-substituted benzoxazine highlighted in the scheme, ANO was superior to reported catalysts such as TFA ${ }^{6 \mathrm{~b}, \mathrm{c}}$ or Oxone. ${ }^{6 \mathrm{~d}}$

(C) 3-Arylquinoxalin-2(1H)-ones are biologically active molecules with great importance in a pharmaceutical context, being structures present in relevant precursors to antidiabetics, anticancer therapeutics, antidepressants, and spasmolytic molecules such caroverine $\left(\right.$ Tinnex $\left.^{\circledR}\right)$. Current approaches to the target structure are based on the use of harsh conditions, flammable volatile organic compounds (VOC), or chlorinated solvents. A new method was developed based on the reaction of $\alpha$-phenylglyoxylic (PGA) and ortho-phenylenediamine, with ANO as catalyst (5 mol\%) in PEG-400 under sonication in an open flask for $10 \mathrm{~min}$, and the corresponding 3-phenylquinoxalin-2 $(1 \mathrm{H})$-one was obtained in $96 \%$ yield. Several $\alpha$-ketoacids were then tested with success. However, the use of substituted ortho-phenylenediamine gives rise to a mixture of regioisomers that can be quantified by ${ }^{1} \mathrm{H}-{ }^{15} \mathrm{~N}$ HMBC NMR spectroscopy. The mechanism is based on initial imine formation, niobium-catalyzed carboxyl activation, and subsequent nucleophilic attack of the second nitrogen of the diamine to furnish the 3 -arylquinoxalin-2(1H)-one. To demonstrate the robustness of this new method, a gram-scale preparation $(5 \mathrm{mmol})$ of the pharmaceutically relevant 3-phenylquinoxalin-2(1H)-one was demonstrated in $87 \%$ yield. $^{7}$

Ultrasound is considered as a green energy source, resulting in reduced energy consumption in some cases by $85 \% .^{7 \mathrm{~b}} \mathrm{ANO}$ is the only catalyst demonstrated for preparation of the three substituted 3-arylquinoxalin-2(1H)-one shown. Notably for 3-(2-bromophenyl)-2(1H)-quinoxalinone, the conventional method of electrochemical cross-coupling with the aryldiazonium salt resulted in $0 \%$ yield. $^{7 c}$

(D) Biodiesel is a biodegradable fuel that is considered a viable substitute for petroleum-derived diesel itself. It can be obtained through the transesterification of vegetable oil (triacylglycerol) with an alcohol in the presence of a catalyst. ANO was used as the catalyst for biodiesel production under reflux or using ultrasound. Conversion of about $90 \%$ was observed for ethyl biodiesel from soya bean oil using ANO as the catalyst in a refluxing system, varying the mass ratio (20\% and $100 \%$ molar ratio catalyst/oil), temperature $\left(25^{\circ} \mathrm{C}\right.$ and $75^{\circ} \mathrm{C}$ ) in ethanol for $24 \mathrm{~h}$. For the ultrasonic conditions, the best result used soya bean oil for $4 \mathrm{~h}$, at $42 \mathrm{kHz}$ in ethanol at $60^{\circ} \mathrm{C}$, achieving a conversion of about $43 \% .^{8}$
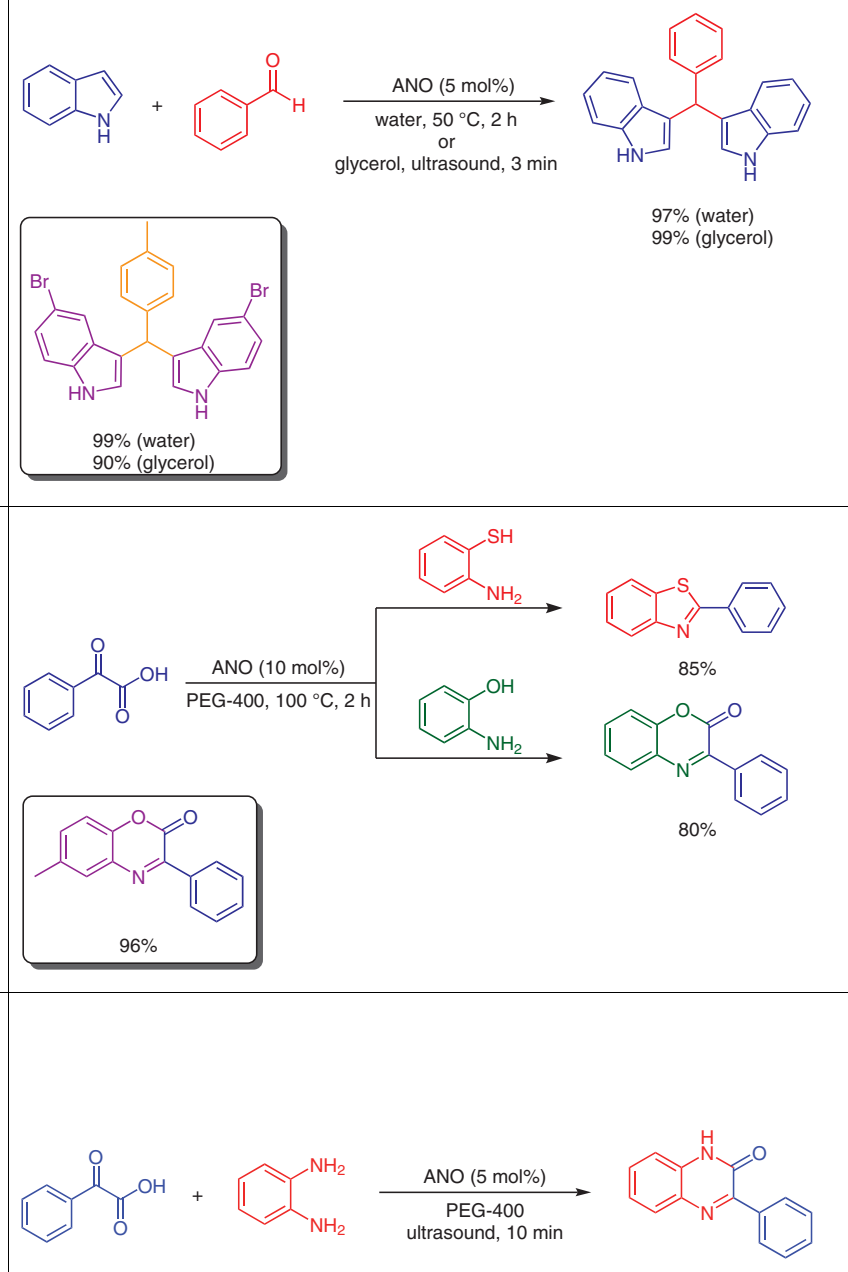

$96 \%$

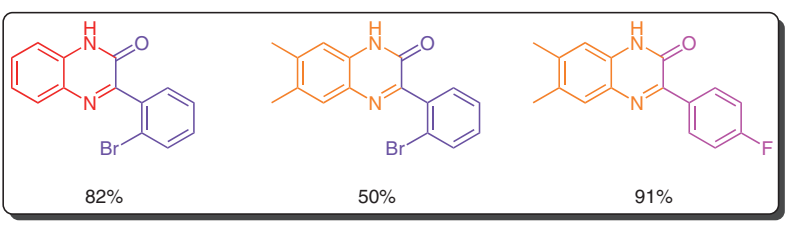




(E) Amide hydrolysis is a significant reaction in industrial and biochemical pro-
cesses, due to its applications in peptide and protein modifications. In a pre-
liminary screening, ANO was applied in the hydrolysis of acetamide under
reflux in moderate yield (45\%) after $20 \mathrm{~h}$. However, the best results of the
study were obtained using the heterogeneous catalyst niobium oxide.

\section{Conflict of Interest}

The authors declare no conflict of interest.

\section{Funding Information}

We acknowledge funding from the Conselho Nacional de Desenvolvimento Científico e Tecnológico.

\section{References}

(1) For selected reviews in applications of $\mathrm{Nb}$ catalysts, see: (a) Marques, A. P.; Fortes, L.; Francisco, M. A. S.; Monte, P. M.; Barros, J. C.; Silva, T. L. Aust. J. Chem. 2020, 74, 219. (b) Marques, A. P.; Almeida, G. C.; Barros, J. C.; Monte, P. M.; Bastos, R. O.; Monteiro, R. S.; Silva, T. L. Ciência Hoje 2019, 356. (c) Almeida, G. C.; Barros, J. C.; Monteiro, R. S. Nióbio : o elemento do século XXI, 1st ed.; SBQ: São Paulo, 2019. (d) Bruziquesi, C. G. O.; Balena, J. G.; Pereira, M. C.; Silva, A. C.; Oliveira, L. C. A. Quim. Nova 2019, 42, 1184. (e) Arpini, B. H.; Bartolomeu, A. A.; Andrade, C. K. Z.; Lacerda, L. C. S. -F.; Lacerda, V. Jr. Curr. Org. Synth. 2015, 12, 570. (f) Lacerda, V. Jr.; Santos, D. A.; Silva-Filho, L. C.; Greco, S. J.; Santos, R. B. Aldrichimica Acta 2012, 45, 19.

(2) (a) Su, T. T.; Zhai, Y. C.; Jiang, H.; Gong, H. J. Therm. Anal. Calorim. 2009, 98, 449. (b) Companhia Brasileira de Metalurgia e Mineração - CBMM. ANO AMMONIUM Niobium Oxalate for the synthesis of your materials (accessed June 28, 2021): http://clientes.pixem.com.br/deconti/cbmm/en/img/Folder_ANOQuimico.pdf.

(3) Sigma-Aldrich. Ammonium niobate(V) oxalate hydrate (accessed June 28, 2021): https://www.sigmaaldrich.com/US/en/product/aldrich/525839.
(4) Anastas, P. T.; Warner, J. C. Green Chemistry: Theory and Practice; Oxford University Press: New York, 1998

(5) (a) Mendes, S. R.; Thurow, S.; Penteado, F.; da Silva, M. S.; Gariani, R. A.; Perin, G.; Lenardão, E. J. Green Chem. 2015, 17, 4334. (b) Khaligh, N. G.; Mihankhah, T.; Johan, M. R.; Ching, J. J. J. Mol. Liq. 2018, 259, 260. (c) Mandal, S. M.; Pegu, R.; Porto, W. F.; Franco, O. L.; Pratihar, S. Bioorg. Med. Chem. Lett. 2017, 27, 2135. (d) Mohapatra, S. S.; Mukhi, P.; Mohanty, A.; Pal, S.; Sahoo, A. O.; Das, D.; Roy, S. Tetrahedron Lett. 2015, 56, 5709. (e) Kalla, R. M. N.; John, J. V.; Park, H.; Kim, I. Catal. Commun. 2014, 57, 55.

(6) (a) Penteado, F.; Vieira, M. M.; Perin, G.; Alves, D.; Jacob, R. G.; Santi, C.; Lenardão, E. J. Green Chem. 2016, 18, 6675. (b) Yan, S.; Ye, L.; Liu, M.; Chen, J.; Ding, J.; Gao, W.; Huang, X.; Wu, H. RSC Adv. 2014, 4, 16705. (c) Ye, Y.; Li, Y.; Zhu, X.; Su, M. CN103739565, 2014. (d) Wang, H.; Yang, H.; Li, Y.; Duan, X. RSC Adv. 2014, 4, 8720.

(7) (a) Ebersol, C.; Rocha, N.; Penteado, F.; Silva, M. S.; Hartwig, D.; Lenardão, E. J.; Jacob, R. G. Green Chem. 2019, 21, 6154. (b) Singh, B. S.; Lobo, H. R.; Pinjari, D. V.; Jarag, K. J.; Pandit, A. B.; Shankarling, G. S. Ultrason. Sonochem. 2013, 20, 287. (c) Jiang, Y.; Dou, G.; Zhang, L.; Xu, K.; Little, R. D.; Zeng, C. Adv. Synth. Catal. 2019, 361, 5170.

(8) Arpini, B. H.; Cubides-Román, D. C.; Javarini, C. L.; Araújo, M. C.; David, G. F.; Santos, R. B.; Romão, W.; Neto, A. C.; Lacerda, V. Jr. J. Braz. Chem. Soc. 2019, 30, 1897.

(9) Siddiki, S. M. A. H.; Rashed, M. N.; Touchy, A. S.; Jamil, M. A. R.; Jing, Y.; Toyao, T.; Maeno, Z.; Shimizu, K. Catal. Sci. Technol. 2021, 11, 1949.

(10) Higa, V. M.; Rocha, W. S.; Sairre, M. I.; Omori, A. T. J. Braz. Chem. Soc. 2021, 32, 1956. 